and heartburn were usefully reduced in $90 \%$, regurgitation in $77 \%$, and vomiting in $70 \%$ of those who had had it. Of 45 patients with adequate radiological follow-up, 15 had radiological evidence of hernia and reflux, 13 of reflux without hernia, and 17 had no radiological evidence of hernia or reflux. The value of the operation to the patient could not be judged from the radiological result.

Attempts to reduce acid secretion did not seem to improve the results, and they added to the morbidity.

Physicians are probably unduly reluctant to recommend surgery in the treatment of hiatus hernia.

We are particularly grateful to Drs. F. Avery Jones and T. D. Kellock and to Mr. J. W. P. Gummer. All the patients included in this survey were in their care; the opinions expressed in this report are entirely ours. We should like also to thank Dr. F. Pygott for information about the number of diagnostic radiological examinations at Central Middlesex Hospital and Miss B. White for assistance with the records. One of us (S. F. P.) was in receipt of a grant from the Royal Australasian College of Physicians as a travelling scholar.

\section{REFERENCES}

Atkinson, M., Edwards, D. A. W., Honour, A. J., and Rowlands, E. N. (1957). Lancet, 2, 918.

Edwards, D. A. W. (1961). Brit. F. Radiol., 34, 474.

(1962). In Surgical Physiology of the Gastro-intestinal Tract, edited by Adam W. Smith, p. 24. Roy. Coll. Surg. Edinburgh. Rex, J. C., Andersen, H. A., Bartholomew, L. G., and Cain, J. C. (1961) 7. Amer. med. Ass., 178, 271.

Wells, C., and Johnston, J. H. (1955). Lancet, 1, 937.

\title{
Ability of Men to Return to Work After Cardiac Infarction
}

\author{
D. E. SHARLAND, ${ }^{*}$ B.SC., M.B., M.R.C.P.
}

Brit. med. F., 1964, 2, 718-720

While the medical problems concerned with the development of ischaemic heart disease have fired the imagination of innumerable workers, the study of the social consequences has been largely neglected. Much of the literature which does consider this facet of the problem comes from the United States of America, and it usually consists of highly selected series-that is, patients seen in private practice or in work classification units-and, moreover, it emanates from a country where a very different social system exists.

Master and Dack (1940), from the U.S.A., report a follow-up of 415 patients of both sexes ranging in age from 30 to 89 who had suffered one, two, or three infarctions. There was an overall rate of return to work of $53 \%$, but if only those under 60 years of age were considered the rate of return was $57 \%$. For all ages the overall rate of return to work after a first infarction was $59 \%$. Those in the higher social categories were more successful than others, so that $84 \%$ of physicians returned to work, in contrast to only 50 to $55 \%$ of those classed as general workers and labourers. Cole, Singian, and Katz (1954) reported a series of 285 patients aged 30-89 who survived for over two months after a first cardiac infarction. Of this group, which included cases complicated by hypertension and diabetes, about two-thirds were able to resume moderate or complete activity ; whether this meant usual work is not entirely clear. In a group of 184 employees of the Eastman Kodak Co. aged 25-64, 82\% were able to resume work, though 20 had to retire prematurely because of total and permanent disability (Crain and Morris, 1956). Papp and Shirley Smith (1951) reported a series of 200 consecutive cases seen in private and hospital practice in this country and showed that in patients whose ages ranged from 30 to $79,65 \%$ of those who suffered cardiac infarction of slight or moderate severity resumed normal activity, while only $33 \%$ of those suffering a severe cardiac infarction were able to resume normal activity, usually in a sedentary occupation. The large difference between these groups was due to the difference in mortality in the first six months after the initial infarction$1.4 \%$ in those sustaining a mild infarction, $5.1 \%$ in those sustaining a moderately severe infarction, and $36 \%$ in those suffering a severe infarction.

The increasing interest in the employability of patients with heart disease in the United States is reflected in the setting up

* Research Registrar, Central Middlesex Hospital, London, in receipt of grant from M.R.C. of cardiac work classification units, the first being started at the Bellevue Hospital in 1941 (Bronstein, 1959).

\section{Present Study}

The present data were obtained during the course of a study of the effects of a low-fat diet compared with an ordinary diet on the progress of ischaemic heart disease. A consecutive series of men were selected for the trial. They were all under the age of 65 , had sustained one episode of cardiac infarction, and were subsequently free from serious complications such as persistent heart failure. Cases where the cardiac infarction was thought to be a complication of an existing disease-for example, diabetes or severe hypertension-were likewise excluded. Many of the men received up to three months' anticoagulant treatment, but none were on long-term anticoagulants. While the details of this dietary study will form the subject of another communication, it may be indicated that there is no evidence of any significant difference in the progress of the men on the two different dietary regimens; for this study they have been grouped together. Men aged 60-64 were excluded as often these had retired or were on the point of retirement. The 212 cases described were collected in approximately four years from three large district general hospitals.

After discharge from hospital every effort was made to get a patient back to work. At the time of entry to the dietary trial information concerning the nature of the job held prior to the cardiac infarction was obtained and, in most cases, the date of return to work, whether it was part-time or full-time

TABLE I.-Status, With Respect to Work, of a Group of Men Under 60 Years of Age Who Survived One Cardiac Infarction and Who Were Followed for One to Three Years up to 31 March 1962

\begin{tabular}{|c|c|c|c|c|c|c|c|c|c|}
\hline \multirow{2}{*}{$\begin{array}{c}\text { Time } \\
\text { after } \\
\text { Initial } \\
\text { Infarct }\end{array}$} & \multirow{2}{*}{$\begin{array}{l}\text { No. of } \\
\text { Patients }\end{array}$} & \multicolumn{2}{|c|}{$\begin{array}{l}\text { No. at Full- } \\
\text { time Work }\end{array}$} & \multirow{2}{*}{$\begin{array}{c}\text { No. at } \\
\text { Part- } \\
\text { time } \\
\text { Work }\end{array}$} & \multirow{2}{*}{$\begin{array}{c}\text { Men at } \\
\text { Work } \\
\text { (F/T } \\
\text { or P/T) }\end{array}$} & \multirow{2}{*}{$\begin{array}{c}\text { No. } \\
\text { not } \\
\text { at } \\
\text { Work }\end{array}$} & \multicolumn{2}{|c|}{ Dead } & \multirow{2}{*}{$\begin{array}{c}\text { No. } \\
\text { Alive } \\
\text { but } \\
\text { Work } \\
\text { Status } \\
\text { Un- } \\
\text { known }\end{array}$} \\
\hline & & $\underset{\text { Job }}{\text { Usual }}$ & $\begin{array}{l}\text { Dif- } \\
\text { ferent } \\
\text { Job }\end{array}$ & & & & No. & $\%$ & \\
\hline $\begin{array}{l}3 \text { months } \\
4=", \\
5 \text { year } \\
\frac{1}{2} \text { years } \\
3 \text { ", }\end{array}$ & $\begin{array}{r}212 \\
212 \\
212 \\
212 \\
171 \\
96\end{array}$ & $\begin{array}{r}58 \\
96 \\
120 \\
138 \\
107 \\
58\end{array}$ & $\begin{array}{l}15 \\
23 \\
33 \\
40 \\
35 \\
16\end{array}$ & $\begin{array}{r}43 \\
35 \\
20 \\
4 \\
5 \\
2\end{array}$ & $\begin{array}{l}55 \% \\
73 \% \\
82 \% \\
86 \% \\
86 \% \\
79 \%\end{array}$ & $\begin{array}{r}89 \\
51 \\
28 \\
15 \\
3 \\
4\end{array}$ & $\begin{array}{r}5 \\
5 \\
7 \\
9 \\
16 \\
13\end{array}$ & $\begin{array}{r}2 \cdot 3 \\
2 \cdot 3 \\
3 \cdot 3 \\
4 \cdot 2 \\
9 \cdot 4 \\
14 \cdot 0\end{array}$ & $\begin{array}{l}2 \\
2 \\
4 \\
6 \\
5 \\
3\end{array}$ \\
\hline
\end{tabular}


and whether it was essentially the same job, was entered routinely in the notes. In a few cases this information had to be obtained retrospectively. Further notes were made on the work status at approximately six-monthly intervals, and the "work status" of the men up to three years after the first cardiac infarction (or to the end of March 1962) is set out in Table I and the Graph. Since the major changes with respect to work status had occurred by six months, the various work groups at that time were selected for further study with a view to identifying any features which might possibly have a predictive value.

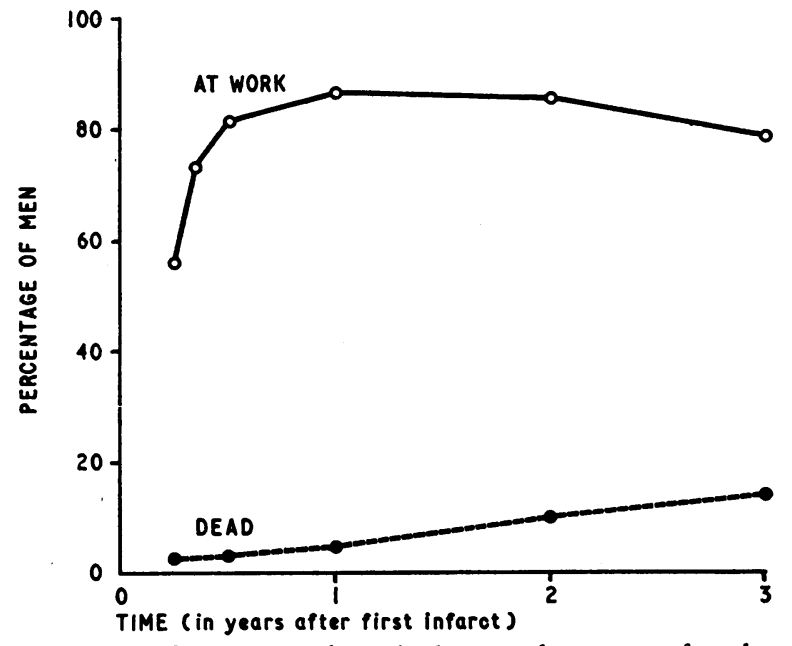

Percentage of men at work or dead up to three years after the first cardiac infarct.

\section{Patients at Part-time Work}

Part-time work is defined as hours, substantially shorter than normal for that particular job-for example, 38 hours per week instead of 44 . Follow-up of the 20 patients who were at parttime work at six months shows that this is usually a temporary phase, 18 of the patients resuming full-time work within 7-18 months of the initial infarction.

\section{Patients at a (Full-time) Different Job}

There was no evidence that the grade of severity ${ }^{1}$ of the initial infarction of these patients differed significantly from that of the whole group $(0.8>\mathrm{P}>0.7)$ (Table II), but there was a greater tendency for these patients to be drawn from social classes IV and V $(0.02>P>0.01)$ (Table III) and to have been

TABLE II.-Grade of Severity of Initial Infarction of 33 Men at Different TABLE II. - Grade of Severity of Initial Infarction of 33 Men at
Work at Six Months Compared with Rest of Group

\begin{tabular}{|c|c|c|c|c|c|}
\hline \multirow{2}{*}{\multicolumn{2}{|c|}{ No. of Men }} & \multicolumn{3}{|c|}{ Severity of Initial Infarct } & \multirow{2}{*}{ Tota } \\
\hline & & Mild & Moderate & Severe & \\
\hline $\begin{array}{l}\text { At different work } \\
\text { Rest of group . }\end{array}$ & $\ldots$ & $\begin{array}{r}6 \\
30\end{array}$ & $\begin{array}{r}22 \\
130\end{array}$ & $\begin{array}{r}5 \\
19\end{array}$ & $\begin{array}{r}33 \\
179\end{array}$ \\
\hline
\end{tabular}

TABLE III.-Social Classification at Time of Initial Infarction of $33 \mathrm{Men}$ at Different Work at Six Months Compared with Rest of Group

\begin{tabular}{cc|c|c|c|c}
\hline \multirow{2}{*}{ No. of Men } & \multicolumn{3}{|c|}{ Social Class* } & Total \\
\cline { 3 - 5 } & & I + II & III & IV + V & \\
\hline $\begin{array}{llll}\text { At different work } \\
\text { Rest of group } . .\end{array}$ & $\cdots$ & 45 & 18 & 12 & 33 \\
\hline
\end{tabular}

* Social classification of General Registry Office.

${ }^{1}$ The initial infarction was classified into three grades of severity: (1) Mild-less than 2 hours' severe chest pain; ST changes in E.C.G. only ; and no constitutional symptoms. (2) Severe-more than 24 hours' severe chest pain; or heart failure ; or hypotension which was persistent or needing hypertensive drugs. (3) Moderate whill cases between 1 and 2 . engaged in active or heavy work $(0.01>\mathrm{P}>0.001)$ (Table IV). The new work was almost invariably recorded as being "lighter" than that prior to the initial infarction.

TABLE IV.-Physical Activity of Occupation at Time of Initial Infarction of 33 Men at Different Work at Six Months Compared with Rest of Group

\begin{tabular}{ll|c|c|c|c}
\hline \multirow{2}{*}{ No. of Men } & \multicolumn{2}{|c|}{ Physical Activity of Occupation* } & \multirow{2}{*}{ Total } \\
\cline { 2 - 5 } & & Light & Active & Heavy & \\
\hline At different work & $\ldots$ & 13 & 14 & 5 & $\begin{array}{r}32 \dagger \\
\text { Rest of group . . }\end{array}$ \\
\hline
\end{tabular}

* Physical activity of occupation classification is that devised by two industrial medical experts and used by the M.R.C. Social Medicine Research Unit (Morris, Heady, Raffle, Roberts, and Parks, 1953).

$t$ The physical activity of one patient in this group was not classifiable.

\section{Patients Not at Work}

Eleven of the 28 men not at work had suffered at various times a further episode of cardiac infarction. Of the remaining 17, only one had obvious signs of progressive ischaemic heart disease, and this man died three years after his first infarction. The remaining 16 had complaints of chest pain and dyspnoea admixed with varying degrees of psychological symptoms and personality difficulties. A review of the severity of the original infarction and of the social class and work-activity classification of this small group did not show any obvious differences from the main group. Of these 16 men, 12 later returned to work.

A study of the small group of 19 men who were not at work or only at part-time work at one year also failed to reveal any distinguishing factor with respect to age, severity of initial infarction, social class, or work activity of usual job. The possible part played by personality was not considered.

\section{Patients at Full-time Work}

A random selection of 23 patients, representing about one in six of those who had resumed their usual job full-time by six months, were chosen for detailed study with a view to ascertaining the extent of their success in this respect. The study was carried out by direct questioning, and while it was essentially subjective it had the advantage that it was carried out on patients who were well known to the questioner.

\section{Summary of Results}

1. Hours of work per week ranged from 44 to 72 .

2. Change in intensity of work: 14 admitted to taking it easier, 7 felt there had been no change, and 2 claimed they were working harder. Those who took it easy did so by consciously slowing their pace and, so far as was possible, by worrying less than before their infarction.

3. Extra assistance at work: three patients had some extra helpfor example, one man with his own business took on a manager, while the other two were given extra help by their employers.

4. Financial changes: 14 patients had no change, 3 earned less, and 2 earned more. (This information was not obtained from four patients.)

5. Sick-leave during the two- to five-year period back at work: 13 patients had no sick leave, 9 had up to one week per year. (One patient was not questioned on this subject.)

The reduction in intensity of work in most cases was apparently due to a change from a particularly "high-pressure" job to that of a more common level-this was achieved by trying to worry less about their work, and by a tendency to avoid overtime. The evidence suggested that the majority of the men carried out a reasonable week's work.

\section{Discussion}

The fact that $55 \%$ of the men were back at work within three months of the onset of the first myocardial infarction suggests 
that there has been a significant change in policy since 1936, when Levine recommended a period of six to eight weeks in bed, with an appropriate convalescent period. Alternatively, it is possible that there is an increasing occurrence or recognition of milder cases.

While most would acknowledge the considerable psychological benefits which are seen in a patient who is able to resume work, there are very few data concerning the physical effects of resumption of work, and it is impossible to answer the oftput questions, "Will I do myself any harm if I go back to work?" or "Should I have another month's rest from work?" The data presented in this series do not provide an answer to these questions except with respect to the mortality (the crudest index) which compares favourably with that recorded in doctors (Morris, Heady, and Barley, 1952; McMichael and Parry, 1960)-the mortality at one year is $4.2 \%$, compared with $4 \%$ of the doctors (who survived the first month after infarction), and at three years is $14 \%$, compared with $10 \%$ in the doctors' series.

Cook, Tuttle, and Kodlin (1962) report from a cardiac workevaluation centre an attempt to establish whether work had any effects on the progress of heart disease. They graded the work capacity of their patients into five categories ranging from normal capacity to confinement to bed. By comparing their assessment at the initial visit with the actual work being carried out when the patients were seen at six-monthly intervals they were able to classify the men into those who complied with the original advice, those who did more than recommended, and those who did less. The mortality of patients suffering from " atherosclerotic heart disease" showed a gradient from $9 \%$ in those who did excessive work, to $5 \%$ in those who complied with advice, and to $3 \%$ in those who did less work than advised. Further studies are needed to confirm if hard work has any adverse effect on those who have suffered from cardiac infarction.

The possible role of psychological stresses has not been considered as it was not possible to measure them.

\section{Summary and Conclusions}

The return to work of 212 men under 60 years of age who have survived one episode of cardiac infarction showed that
$55 \%$ were back at work within three months and $82 \%$ within six months.

The major changes in employment "status" had generally been achieved within six months of the initial cardiac infarction, and the various employment subgroups at this stage were therefore studied more closely. (a) Part-time work was usually a temporary phase which was ultimately followed by a return to full-time work. (b) A change of job was more common in those in social classes IV and $\mathrm{V}$ and those normally undertaking active or heavy work. (c) A review of the social class, physical activity of work, and severity of initial infarction of the few men who were not at work at six months (and who had not suffered any further episodes of cardiac infarction) did not show any obvious distinguishing features. (d) Study of a sample of those who resumed full-time work within six months indicated that while the majority tended to take it easier than formerly they were still doing a reasonable job of work and were not being "carried" by their employers.

The death rate in the first three years after the initial infarction did not suggest that the high rate of return to work had any adverse effect.

The effects of heavy manual work and of mental stress on the progress of men who have suffered from myocardial infarction are still largely speculative.

I am grateful to Dr. K. P. Ball, Professor J. N. Morris, and Dr. J. A. Heady for their advice and encouragement received while carrying out this study.

\section{REFERENCES}

Bronstein, L. H. (1959). In Work and the Heart, edited by F. F. Rosenbaum and E. L. Belknap. Hoeber, New York.

Cole, D. R., Singian, E. B., and Katz, L. N. (1954). Circulation, 9, 321. Cook, W. L., Tuttle, W. B., and Kodlin, D. (1962). F. occup. Med., 4, 411.

Crain, R. B., and Morris, E. M. (1956). N.Y. St. F. Med., 56, 2238. Levine, S. A. (1936). Clinical Heart Disease. Saunders, Philadelphia. McMichael, J., and Parry, E. H. O. (1960). Lancet, 2, 991.

.

Morris, J. N., Heady, J. A., and Barley, R. G. (1952). Brit. med. F., 1, 503 .

Raffle, $P$.

Lancet, 2, 1053.
Papp, C., and Shirley Smith, K. (1951). Brit. med. F., 1, 1471.

\title{
Effect of Propranolol (Inderal) in Angina Pectoris : Preliminary Report
}

\author{
J. HAMER,* M.D., M.R.C.P. ; T. GRANDJEAN,* M.D. ; L. MELENDEZ,* M.D. ; G. E. SOWTON,* M.B., M.R.C.P.
}

Brit. med. F., 1964, 2, 720-723

The increase in the force of ventricular contraction when the cardiac sympathetic nerves are stimulated suggests that sympathetic activity may be an important determinant of the response of the heart to exercise (Rushmer, Smith, and Franklin, 1959 ; Sarnoff and Mitchell, 1961). However, the improvement in exercise tolerance that follows sympathectomy in patients with angina pectoris (Apthorp, Chamberlain, and Hayward, 1954) indicates that the increased ventricular contractility produced by sympathetic stimulation may be undesirable when

* From. the Institute of Cardiology and the National Heart Hospital, London. myocardial blood-flow is restricted. The cardiac sympathetic system consists of beta-adrenergic receptors (Ahlquist, 1948), which are specifically blocked by pronethalol (Black and Stephenson, 1962). There is evidence that this drug is helpful in angina pectoris (Dornhorst and Robinson, 1962 ; Alleyne et al., 1963 ; Apthorp et al., 1964), but its use has been restricted by undesirable side-effects (Paget, 1963). The recent introduction of a new analogue (Fig. 1) without these drawbacks (Black, Crowther, Shanks, Smith, and Dornhorst, 1964) has allowed fresh assessment of the response to beta-adrenergic blockade. A standardized exercise-tolerance test has been used to determine 